\title{
Covid-19 and Law: The Legal Science of the XXI Century in the Age of the 'Great Pandemic'
}

\author{
Riccardo Cardilli \\ Full Professor of Roman Law \\ Tor Vergata Rome University (Italy)
}

Cita recomendada. CARDILLI, R., Covid-19 and Law: The Legal Science of the XXI Century in the Age of the 'Great Pandemic', dA. Derecho Animal (Forum of Animal Law Studies) 11/4 (2020). - DOI https://doi.org/10.5565/rev/da.529

\begin{abstract}
The real meaning of the words 'epidemic' and 'pandemic'. The pandemic in history: the Antonine plague in the Roman Empire and the epidemic in Athens. The issue of the role of law in managing extraordinary events: the modern perspective and the Roman law perspective in comparison. Carl Schmitt's theory of 'Ausnahmezustand' and the need to overcome this model. The importance of law and legal science in times of emergency.
\end{abstract}

Key words: Emergency; Law; Pandemic; Democracy.

\section{Resumen - Covid-19 y Derecho: La ciencia jurídica del siglo XXI en la era de la 'Gran Pandemia'}

El significado real de las palabras "epidemia" y "pandemia". La pandemia en la historia: la peste Antonina en el Imperio Romano y la epidemia en Atenas. La cuestión del papel del derecho en la gestión de eventos extraordinarios: la perspectiva moderna y la comparación con la perspectiva del derecho romano. La teoría de Carl Schmitt de 'Ausnahmezustand' y la necesidad de superar este modelo. La importancia del derecho y la ciencia jurídica en los periodos de emergencia.

Palabras clave: Emergencia; Derecho; Pandemia; Democracia. 


\section{Virus and History}

Since the appearance of the Covid-19, between December 2019 and January 2020 in China ${ }^{1}$, the viral pneumonia caused by it has spread gradually throughout the world, hitting the countries of East Asia first, then Central Asia and Europe, and finally Africa and the Americas. Its propagation speed was directly proportional to the speed of 21 st century airline links between the various continents of the earth. The absence of specific treatments for the virus and its aggressiveness, in terms of serious lung and heart infections, have made Covid-19 a real scourge for humanity.

The meanings of words, from their appearance in human history, sometimes settle on the bottom of a blanket of new meanings that are recognized over time, overlapping the first. Historically, the culture of a human community can unknowingly forget these deeper layers of meaning, but as often happens for those unpredictable processes of the history of ideas, they can again be made very current and shake off the linguistic torpor in which they had fallen, to impose themselves with strength in the minds of contemporaries.

One of these words is 'epidemic', and another its related 'pandemic'. They have assumed a specialized meaning in the scientific language of medicine with a clear element of distinction in terms of the extent of the infection:

«Epidemic, an occurrence of disease that is temporarily of high prevalence. An epidemic occurring over a wide geographical area (e.g., worldwide) is called a pandemic.»

«Pandemic, outbreak of infectious disease that occurs over a wide geographical area and that is of high prevalence, generally affecting a significant proportion of the world's population, usually over the course of several months. Pandemics arise from epidemics, which are outbreaks of disease confined to one part of the world, such as a single country»

(Medicine Encyclopedia Britannica)

The semantic relationship is of a conventional synonymous nature, in relation to genus-species, characterized by the specific difference that the pandemic is an epidemic that invades vast territories.

This is not, however, the original meaning. The word epidemía in Hippocrates and Galen expresses a loimós (in Latin pestis) that infects a large community of men. The word 'epidemic' and in its related 'pandemic' - words built by derivation - in reality come from the Greek word 'demos', which means people and has a predominant role, from which, for example, 'democracy' comes, in the sense of government / power of the people ${ }^{2}$. In the epidemic and pandemic, the prefixes epi (up / above) and pan (all) specify their meaning in the sense of what falls on the people, strengthening pan in the sense of all people. In the original meaning of the Greek word, the territorial dimension, then reflected in modern languages for the difference between epidemic and pandemic, is not significant, the relational dimension connected to the human community involved being predominant. In the language of medical science (since ancient times), by metonymy, the above-mentioned words have acquired the specialist meaning of viral or bacterial diseases with extensive and uncontrolled propagation, in the sense of 'pernicious plague'. ${ }^{3}$

In Latin sources the word pestilentia derived from pestis, recurs with the meaning of the Greek 'epidemic' to describe the effects of an infectious disease with a wide impact on the population ${ }^{4}$.

\footnotetext{
${ }^{1}$ On the problem of its natural or artificial origin, see ANDERSEN, K.J., RAMBAUT, A., IAN LIPKIN, W., HolmeS, E.C. and GARRY, R.F., The proximal origin of SARS-CoV-2, in Nature Medicine (26 April 2020) 450-455. On the international tensions generated by the accusations between the various countries regarding the problem of containing the epidemic, see EMMONS, C., International Human Rights Law and COVID-19 States of Emergency (2020), in Verfassungsblog- online.

${ }^{2}$ On the conceptual deconstruction of the modern word 'democracy' (essentially understood, in modern constitutionalism, in the form of the so-called representative democracy) to understand the original meaning of 'democracy' in ancient philosophical, political and historiographical thought, see CANFORA, L., Democrazia. Storia diuna ideologia (Rome-Bari, 2006). On the relationship between Greek 'democracy' and the different idea of res publica as res populi (see Cicero De re publica I, 26, 39-41.) in Roman public legal thought, see Catalano, P., Populus Romanus Quirites (Turin, 1971); LoBrano, G., Res publica res populi. La legge e la limitazione del potere (Turin, 1990) $111 \mathrm{ff}$. On the relationship between democratic principle and Roman public law, with non similar interpretations, see CAtAlano, P., The democratic principle in Rome, (in italian) in Studia et Documenta Historiae Iuris 28 (1962) 316 ff. and De Martino, F., La costituzione della città-stato, in Momigliano, A., and Schiavone A. (eds.), Storia di Roma, vol. I. Roma in Italia (Turin, 1988) $345 \mathrm{ff}$.

${ }^{3}$ Galenus, in Hipp. comm. 2.1 ss.

${ }^{4}$ See on pestilentia in the third of notiones deorum of Cic. de nat. deor. 2. 13-14: Cleanthes quidem noster quattuor de causis dixit in animis hominum informatas deorum esse notiones, primam posuit eam, de qua modo dixi, quae orta esset ex praesensione rerum futurarum; alteram, quam ceperimus ex magnitudine commodorum, quae percipiuntur caeli temperatione, fecunditate terrarum aliarumque commoditatum complurium copia; [14] tertiam quae terreret animos fulminibus, tempestatibus, nimbis, nivibus, grandinibus, vastitate, pestilentia, terrae motibus et saepe fremitibus lapideisque imbribus et
} 
In the face of numerous epidemics that were more or less territorially extended, the ancient Greek and Roman sources recall four large pandemics that broke out in antiquity: the plague that hit Athens between 430 $\mathrm{BC}$ and $426 \mathrm{BC}$ - the Antonine plague - remembered by Thucydides, who ruled over the Roman Empire between $165 \mathrm{AD}$ to $180 \mathrm{~A}$.D.; the so-called plague of Cyprian around $250 \mathrm{AD}$, and finally the Justinian plague of 541 A.D ${ }^{5}$. Of these, one above all seems to have had devastating effects: the Antonine plague, which scourged the empire for more than ten years and, according to some ancient historians, even killed emperors Marcus Aurelius and Lucius Verus. Consistent with a deterministic method of interpreting historical facts, ancient historiography strives to grasp the proximate causes of events, mostly with anecdotal orientations, where what a historiographical school of the twentieth century - that of the Annales - indicates regarding the permanent and long-run factors in history may not always be grasped.

The historian Ammianus Marcellinus (ca.330-332 AD - ca.397-399 AD) in his rerum gestarum libri XXXI hands down an anecdotal explanation of the proximate cause of the serious epidemic that occurred under the emperors Marcus Aurelius and Lucius Verus, known precisely as the 'Antonine plague'.

\begin{abstract}
Amm. Marc. 6.23-24
«Once conquered $<$ the city of Seleucia $>$ by the generals of $<$ Lucius $>$ Verus Caesar - as we have narrated previously - the statue of Apollo Comeo ( $=$ Cumeo) was removed from its seat and brought to Rome and here the priests placed it in the temple of Apollo Palatine. It is said that after the raiding of this statue, while the city was on fire, some soldiers, who rummaged in the temple, found a narrow hole and, hoping to find something precious, opened it and from a closed recess with magical formulas inscribed on it of the Chaldeans a primordial pestilence sprang out which, produced by the force of incurable diseases (insanabilium vi concepta morborum), contaminated with contagions and deaths the whole empire from the same borders of Persia up to Gaul and the Rhine, at the time of the same Verus and by Marcus $<$ Aurelius $>$ Antoninus» ${ }^{6}$
\end{abstract}

The army of Marcus Aurelius, under the leadership of Lucius Verus, defeated the Parthians in Seleucia on the Tigris, in 164 AD. The facts as narrated by Ammianus, whose historical method was characterized by research in the field, in archives and libraries, through official reports, but also thanks to the oral recollection of historical events by the protagonists, ${ }^{7}$ is pervaded by a moralizing vein, aimed at stigmatizing the behavior of the Roman soldiers who, in their greed, not satisfied with the removal of the statue of Apollo, symbol of the conquered city, open a chest in the temple with Caldee inscriptions, and end up unleashing the violence of the plague throughout the Empire. The real cause of the epidemic would not have been as random as the sacrilegious conduct of the Roman army in Seleucia. The particularly effective concatenation of events in the sequence "quod post direptum hoc idem figmentum / contagiis polluebat" highlights how a deeper layer is connected to a descriptive reading, which denotes Ammian's historical judgment on the causes of the serious epidemic. The strength of the image of the labes primordialis, quae insanabilium there conceived morborum ... contagiis polluebat, clearly shows the unstoppable spread of the epidemic in the territories of the Roman Empire.

In Latin sources there is another extraordinary testimony of the effects on the 'people' of an epidemic, from the de rerum natura of Lucretius Carus.

\title{
Lucretius De rerum natura VI. 1138-1153
}

"Once upon a time, this type of disease and deadly flow scattered the fields of corpses in the reign of Cecrope [mythical king of Athens] devastated the streets and emptied the city of inhabitants. In fact, born from the innermost parts of Egypt, after having crossed vast regions of sky and floating marine

\footnotetext{
guttis imbrium quasi cruentis, tum labibus aut repentinis terrarum hiatibus...

${ }^{5}$ GILliam, J.F., The Plague under Marcus Aurelius, in The American Journal of Philology 82/3 (1961) 225 ss.; HARPER, K., Pandemics and passages to late antiquity: Rethinking the Plague of 249-270 described by Cyprian, in Journal of Roman Archeology, 28 (2015) 223 ss. Little, L.K., (ed.), Plague and the End of Antiquity. The Pandemic of 541-750 (Cambridge, 2007).

${ }^{6}$ Qua per duces Veri Caesaris, ut ante rettulimus, expulsata, avulsum sedibus simulacrum Comei Apollinis perlatumque Romam in aede Apollinis Palatini deorum antistites collocarunt. fertur autem quod post direptum hoc idem figmentum incensa civitate milites fanum scrutantes invenere foramen angustum, quo reserato, ut pretiosum aliquid invenirent, ex adyto quodam concluso a Chaldaeorum arcanis labes primordialis exiluit, quae insanabilium vi concepta morborum eiusdem Veri Marcique Antonini temporibus ab ipsis Persarum finibus ad usque Rhenum et Gallias cuncta contagiis polluebat et mortibus. See DE BOEFT, J., DRIJVERS, J.W., Den Hengst, D., Teitler, H.C., Philological and Historical Commentary on Ammianus Marcellinus XXIII (Groningen, 1998) 158 ss. [translation by the author].

${ }^{7}$ On the historical method of Ammianus Marcellinus see. SABBAH, G., La méthode d'Ammien Marcellin. Recherches sur la construction du discours historique dans les res gestae (Paris, 1978).
} 
expanses it finally fell upon all the people of Pandion [another legendary king of Athens] and then heaps fell prey to disease and death. At the beginning, their heads were burning with a fiery ardor and both eyes red with a diffuse glow the black jaws also sweated blood inside blocked with sores the way of the voice was closed, and the tongue, interpreter of the soul, drops of blood oozed, weakened by evil, clumsy in movement, rough to the touch. Then, through the throat, it invaded the lungs and flowed into the afflicted heart of the sick, back then all the barriers of life really wavered". ${ }^{8}$

The Roman poet and philosopher of the $1^{\text {st }}$ century BC, follower of the current of Epicureanism, draws with particular efficacy the effects of the epidemic that hit Athens between $430 \mathrm{BC}$ and $426 \mathrm{BC}$.

In ancient times the most important source on the serious pestilentia that had hit Athens, the democratic polis par excellence, had been Thucydides in $5^{\text {th }}$ century BC. ${ }^{9}$

The serious epidemic is described by Lucretius as a ratio morborum et mortifer aestus, with a very effective image that denotes the strength of the disease and its deadly spread. The effects on the city are captured (qualified by Lucretius as urbs) ${ }^{10}$ : first of all its impact on the agricultural production of the fields, then the devastation of the roads and finally the emptying of the urbs as its own citizens left (funestos reddidit agros / vastvitque vias, exhausit civibus urbem).

The poet's gaze is sensitive to the powerful "duel between the forces of life and those of death", ${ }^{11}$ with a detailed description of the effects of the disease and of the sense of absence and emptiness that propagated the city, aimed at grasping its extensive effects on the populus. In essence, in Lucretius there is a so-called 'naturalistic' reading of the event, but also a political-sociological reading. Not only are the heavy consequences in terms of deaths and the sick to be highlighted in the reflection by the Roman poet and philosopher, but also those relating to the 'political' holding of the 'city-state', which entail the disappearance of the conventional component, founding element of the democratic polis, of the relationship between citizens and rulers.

The small glimpse that can be seen in the text of Lucretius has an essential matrix in Thucydides (ca. 460 BC - ca. 404-399 BC). In his Stories, in fact, there is a fundamental passage, in which, after having made a detailed description of the origin of the epidemic, of its impact on the city of Athens and its citizens, of the symptoms of the same (Thuc. hist. 2.47 .3-2.52), Thucydides devotes a few lines to the political consequences of the epidemic precisely on the holding of the polis, as a consequence of the despair that had seized its citizens for the subversion of all economic certainty and life expectancy (Thuc. hist. 2.53 .1-3).

Thucydides, hist. 2.53.4:

«No restraint <represented> divine fear (theôn phóbos) or the law of men (antrópon nómos): respect and sacrilege were not distinguished by those who witnessed the daily spectacle of a death that struck without distinction, blindly. Furthermore, no one conceived the serious fear of coming alive to account for their crimes to justice. They felt a much heavier sentence hanging over their heads: and before it fell, it was human to try to enjoy some life.» ${ }^{12}$

The consequences of the epidemic go from being serious from a health point of view to being serious for the economy and in general for the 'political' stability of the polis. In this regard it is illuminating to grasp the impact of the disease on the Athenians, as the survivors reinterpreted the ancient oracle "the Doric war and the plague (loimós) will come with it", discussing whether it had actually referred to it as a 'hunger' (limós), rather than as a 'pestilence' (Thuc. hist. 2.54.2-3). Loimós and limós is a pun of words (paronomasia) that express a polarity, not characterized by the true-false binomial, but by that of the reality that the city community was experiencing.

\footnotetext{
${ }^{8}$ Haec ratio quondam morborum et mortifer aestus / finibus in Cecropis funestos reddidit agros / vastavitque vias, exhausit civibus urbem. / Nam penitus veniens Aegypti finibus ortus, / aera permensus multum camposque natantis, /incubuit tandem populo Pandionis omni. / Inde catervatim morbo mortique dabantur./ Principio caput incensum fervore gerebant / et duplicis oculos suffusa luce rubentis./ Sudabant etiam fauces intrinsecus atrae / sanguine et ulceribus vocis via saepta coibat / atque animi interpres manabat lingua cruore / debilitata malis, motu gravis, aspera tactu. / Inde ubi per fauces pectus complerat et ipsum / morbida vis in cor maestum confluxerat aegris,/ omnia tum vero vitai claustra lababant. [translation by the author].

${ }^{9}$ Thucydides historiae 2.47.3- 2.54.

${ }^{10}$ For the substantial difference between the Roman concept of $u r b s$, its correlate of civitas and the Greek polis, see CACCIARI, M., La città (Rimini, 2009) 7 ss.

${ }^{11}$ DiOnigi, I., Lucrezio: Le cose e le parole (Bologna, 1988) 90.

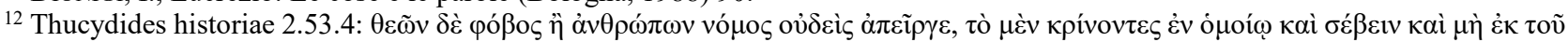

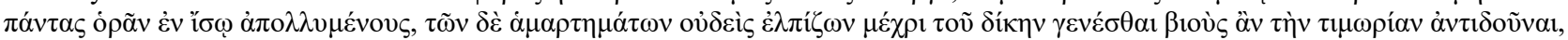

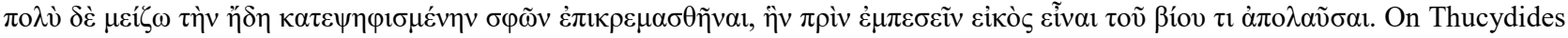
see CANFORA, L., Tucidide. La menzogna, la colpa, l'esilio (Roma-Bari, 2016).
} 
On the other hand, Thucydides was a direct witness of this, as he himself takes care to say ("My relationship is based on personal experiences: I have suffered from the disease and I have observed its course in others"; hist. 2.48 i.f.).

Precisely this duality of effects, expressly indicated in Thucydides, but which is also echoed in the passage of Lucretius' de rerum natura, has an illuminating value today, on what is happening at the time of Covid-19.

The impression left by the dualism (epidemic - hunger) is confirmed and could be expressed in the contrast between the effects of the virus on the physical body of men and the effects of the same on the political body of citizens or, if we want, in the tension between virus and demos / populus. In Thucydides' description the balance seems to be inexorably leaning in favor of the former, given the disintegration of the demos not stemmed by the nomos.

This represents, in my opinion, an enriching historical key to reading the problem posed by the coronavirus pandemic in the current times compared to the forms and legal contents with which modern states are facing it.

\section{Pandemic and the Modern State: 'necessitas non habet legem'}

The ongoing pandemic has determined, as Thucydides had already guessed with respect to Athens, a cause of a strong crisis in the holding of the democratic polis. In the current situation, its impact on the ability of state political forms, in their various forms, to provide an effective reaction to the state of need that has come about, with appropriate legal instruments for the purpose, is similarly understood.

Are the contemporary nomos and ius proving to be an adequate tool, and at what price for emergency management?

A first aspect that I want to highlight is the emergence of 'chaos'. Since the appearance of the virus and the perception of its devastating effects on human health, the responses that single states have developed in the exercise of their sovereignty over the affected territories have not been unambiguous and have been strongly affected by their different political organization. It is normal that a country with a strong centralized management structure over national territory orients itself to fix univocal answers on that national territory, while one characterized by a federal model or decentralized with autonomy competences over smaller territorial public bodies orients itself to diversify the policies according to the territorial spread of the virus.

Hence, in the second constitutional forms, a high decision-making conflict arose in connection with solutions that might have seemed sensible from a national or federal perspective, but were not so from a regional or individual federated point of view.

And here the first serious paradox has already been highlighted from a legal perspective: that of the difficulty of single states to effectively face the spread of the virus, as that of national law and sovereignty, as a profound historical conditioning of the political and international life of contemporary law, it is an element of strong resistance against a swift and effective response to a pandemic virus. In other words, the confinement of law to national spaces of the modern state cannot face problems of a global dimension. Difficulties not new, already widely experienced in terms of the effort to create spheres of law in an ultra-state dimension and an effective response to supranational problems (such as terrorism and natural disasters).

To the first paradox is added another: the oxymoron of 'democracy in a state of exception' ${ }^{13}$. Faced with an exceptional situation that is presumed to be unable to be addressed with the tools constitutionally provided for in the normal course of the democratic life of a state, modern constitutionalism, with a normative and formal imprint, has great difficulties in finding adequate and effective response mechanisms on the regulatory plan, without affecting the democratic foundations of its very existence. The risk for 'democratic' states, from this point of view, is to reveal their more ideological side, proving to be unsuitable for building an effective response to deal with the virus through a legal form that does not deny itself, i.e. the 'Ausnahmezustand'.

The juridical thought of the twentieth century had already placed these types of problems at the center of the question of the difficulty for the state, at least in its formal and normative constitutional representation, of expressing within it effective instruments of defense against a serious and irresistible looming risk.

The response that Carl Schmitt gave to the problem in $1921{ }^{14}$ was surprising, but also very lucid. Indeed, historically retracing the ideology of the juridical institution of the dictatorship, from the Roman dictator up to the 'dictatorship' of the proletariat of Lenin, he identified two of its main declinations: the commissioner, and the sovereign dictatorship, which, while based on content different from the relationship between power and law, would both realize the paradox of the state of exception. In order to defend the greater good, that is,

\footnotetext{
${ }^{13}$ See Lemke, M., Demokratie im Ausnahmezustand. Wie Regierungen ihre Macht ausweiten (Frankfurt/New York, 2017).

${ }^{14}$ Schmit, C., Die Diktatur von den Anfängen des modernen Souveränitätsgedankens bis zum proletarischen Klassenkampf (München und Leipzig, 1921).

68 Derecho Animal. Forum of Animal Law Studies, vol. 11/4
} 
the conservation and safeguarding of the state in the face of a serious impending risk, they would inevitably have to attack it. In its most intimate essence, dictatorship, therefore, seems itself a constitutional anomaly; or rather it could be called the anomaly par excellence. The dialectic between protecting and at the same time attacking, undermining the foundations of that it wants to protect. From Schmitt's perspective, it is clear that dictatorship as a necessary consequence of the state of exception assumes all its configuration limits with respect to law. Just as the latter is a phase of suspension of fundamental rights and freedoms, so the former is itself difficult to classify in law, if not in terms of effectiveness ${ }^{15}$.

This reveals a conceptual superstructure of contemporary legal thought which tends to relegate that which is not order and norm, that which is not formally valid according to the constitutional parameters given, in the world of fact.

The Roman one is antithetical to this perspective, where the ius (and not only the lex) has a wide pervasiveness. In the complex history of the Roman Republic (from the royal to the republican model, from the latter to the imperial model) emerges a conception of the ius in a non-static key, but dynamic, substantial and non-formal, which is also inexorably reflected in the ability to include in the law the conflict and the exceptional nature, so much so as to make them elements of stimulus and effective tools for the development of what we could call the 'Roman constitution' ${ }^{16}$. A fundamental ancient roman idea is that conflict and exceptionality are not perceived as exclusive expressions of 'facts', but actually they are already in the 'legal reality' not denying their exceptional nature ${ }^{17}$.

In Rome, for example, the historical category of 'revolution' must be used very carefully - as fundamental as it is to understanding the developments of European and American history of the seventeenth to twentieth centuries - as there is not so much the idea of revolution in the modern sense, with the effective imposition of a new legal order, as the factual basis (so-called principle of effectiveness), of the birth of a new legal order ${ }^{18}$. The ius of the Romans is essentially an instrument of inclusion of the conflict which, even in its dynamics, is not contrary to the law, but a juridical factor of development, in a perception of the juridical continuum which, despite the profound changes of the political-juridical forms of its realization, can be expressed in the unitary category of the Imperium Romanum ${ }^{19}$.

This has precise consequences on the Roman perception of what Carl Schmitt called the 'Ausnahmezustand'. In the dictatorship of the ancients ${ }^{20}$, that is, at least until its forced reinterpretation in the key of life magistracy with Cornelius Silla and the lex de Sulla dictatore of $82 \mathrm{BC}$, the dictatorship is not perceived as a state of suspension of the law to manage an extraordinary situation, but as a fully adequate legal instrument to manage exceptional moments. The mandatory principle of its fully legal configuration is given by the mandatory (fas) temporary limit of his 'power' (maximum six months) and purpose of this type of magistrate ${ }^{21}$. It is therefore not the dialectic between law and fact, but that of the holding of constitutional

\footnotetext{
15 There is now a tendency, in relation to justifying the dictatorial trend of world governments to manage the pandemic in action, to distinguish between a state of emergency and a state of exception, as if in this way the underlying legal problem resolves itself and then, if the suspension of constitutionally recognized fundamental rights is caused by the emergency and not by the exception, it is in itself admissible and justifiable. See now AGAMBEN, G., online https://www.quodlibet.it/giorgio-agamben-stato-di-eccezione-e-statodi-emergenza .

${ }^{16}$ See SERRAO, F., Diritto private, economia e società, I (Napoli, 2004); SCHIAvONE, A., The Invention of Law in the West (CambridgeLondon, 2005). CApogrossi Colognesi, L., Storia di Roma tra diritto e potere (Bologna, 2014); Cerami, P. - Miceli, M., Storicità del diritto. Strutture costituzionali, fonti, codici. Prospettive romane e moderne (Torino, 2018).

${ }^{17}$ In this context, I recall two examples which, however, I consider significant in order to corroborate what I have said somewhat apodictically: the first is the patrician-plebeian conflict that is embodied in the model of struggle of the secession (not revolution, mind you) of the plebs and the continuous separation and reunion of the two communities of Roman citizens for a more egalitarian and just transformation of the relations between them both in a political-constitutional key and in a private law key for the Republic. The second is the moment of crisis of the Republic (II-I Century BC.), which opens (in a key of very strong tension and also armed clashes in the city) with the use of an ancient religious-juridical rite proper by Scipio Nasica, princeps senatus, to denounce the high treason committed (according to him) by Tiberius Gracchus. Conflict tends to break public harmony and produce new forms of dialogue and order, in a continuous and magmatic development of the law in action.

${ }^{18}$ For a Roman law critique of the relationship between fact and law as thought in the modern conception, see CATALANO, P., Diritto e persone (Torino, 1990) vii ss.

${ }^{19}$ Catalano, P., Impero: un concetto dimenticato del diritto pubblico, in Cristianità ed Europa. Miscellanea di studi in onore di L. Prosdocimi, II (Roma, 2000) 29 ss. It is important not to confuse the ancient Roman concept of imperium with the modern one of 'imperialism', as happens, in my opinion, in HARDT, M. and NEGRI, A., Empire (Harvard, 2001).

${ }^{20}$ On the contrast between the dictatorship of the ancients and the dictatorship of the moderns, of importance is the collective volume Meloni, G. (ed.), Dittatura degli antichi e dittatura dei moderni (Roma, 1983).

${ }^{21}$ D. 1.2.2.18 Pomp.1.s. ench.: Hunc magistratum, quoniam summam potestatem habebat, non erat fas ultra sextum mensem retineri. On the dictatorship in republican age see MoMMSEN, Th., Römische Staatsrecht, II.1 (Leipzig, 1877) 151-153; DE MARTINO, F., Storia della costituzione romana, I (Napoli, 1972) 236-250; 275-285; MEloni, G. (ed.), Dittatura degli antichi e dittatura dei moderni, cit.; LABRuna, L., Adversus plebem dictator, in Index 15 (1987) 289 ss. [= Idem, Civitas quae est constitutio populi e altri studi di storia costituzionale romana, Napoli (1999) 45 ss.]; MASi Doria, C., Spretum imperium (Napoli, 2000) 137 ss.; CASCIONE, C., Dictatorem dicere. Critica di un dogma (moderno) del diritto pubblico romano, in Studi per G. Nicosia, II (Milano, 2007) 269 ss. [= Idem, Studi di diritto pubblico romano (Napoli, 2010) 9 ss.].
} 
forms to an exceptional situation through a legal instrument recognized as a way to deal with it.

\section{Conclusions}

The modern perspective clearly affects all the sensitive contents of law of modern democratic states, which, in terms of stability and functioning, find it difficult to develop adequate solutions without denying themselves. The denial of oneself, even if creeping or implicit, could be a serious harbinger of a future antidemocratic period.

The game being played, therefore, even if it would often seem almost unconscious, is that of the republican and democratic values of many countries in the world, with a legal science that seems to remain immobile and statically firm to the formal contents of the constitution, instead of dynamically oriented to the defense of the substantial and fundamental nucleus of the law within the various communities involved. In essence, it is necessary to react to the deep and rooted idea in our juridical feeling that necessitas non habet legem.

Only on the level of ius and nomos is the real game being of how to face the pandemic without denying our fundamental values being played.

The challenge that awaits us is particularly difficult, but as Dr. Bernard Rieux says in The Plague of Albert Camus: "In the midst of the scourges one learns that in men there are more things to admire than to despise". 